\title{
Convergent development of low-relatedness supercolonies in Myrmica ants
}

\author{
T van der Hammen ${ }^{1}$, JS Pedersen ${ }^{1,2}$ and JJ Boomsma ${ }^{1}$ \\ ${ }^{1}$ Department of Population Ecology, Zoological Institute, University of Copenhagen, Universitetsparken 15, DK-2100 Copenhagen, \\ Denmark; ${ }^{2}$ Institut d'Ecologie - ZEA, Université de Lausanne, Bâtiment de Biologie, CH-1015 Lausanne, Switzerland
}

\begin{abstract}
Many ant species have independently evolved colony structures with multiple queens and very low relatedness among nestmate workers, but it has remained unclear whether lowrelatedness kin structures can repeatedly arise in populations of the same species. Here we report a study of Danish island populations of the red ant Myrmica sulcinodis and show that it is likely that such repeated developments occur. Two microsatellite loci were used to estimate genetic differentiation $\left(F_{\mathrm{ST}}\right)$ among three populations and nestmate relatedness within these populations. The $F_{\mathrm{ST}}$ values were highly significant due to very different allele frequencies among the three populations with relatively few common alleles and relatively many rare alleles, possibly caused by single queen foundation and rare subsequent immigration. Given the isolation of the islands and the low investment in reproduction, we infer that each of the populations was most likely established by a single queen, even though all three
\end{abstract}

extant populations now have within-colony relatedness $<0.06$. All populations can be regarded as supercolonies with high nest densities and competitive monopolisation of the habitat patch excluding all other ant species. The investment in new sexuals was extremely male-biased (>95\%), and the genetic differentiation of nests showed a significantly positive correlation with the distance between them. Both male-biased sex-ratio and genetic viscosity are expected characteristics of populations where queens have very local dispersal and where new colonies are initiated through nestbudding. Based on a comparison with other $M$. sulcinodis populations we hypothesise a distinct succession of population types and suggest that this may be a possible pathway to unicoloniality, ie, development towards a complete lack of colony kin structure and unrelated nestmate workers.

Heredity (2002) 89, 83-89. doi:10.1038/sj.hdy.6800098

Keywords: social insects; Myrmica sulcinodis; microsatellites; relatedness; population viscosity; unicoloniality

\section{Introduction}

In eusocial insects, workers increase their inclusive fitness by rearing the brood of related individuals (Hamilton, 1964). The workers thus have an interest in keeping within-colony relatedness high. This is indeed the case when nestmate workers are the offspring of a single, once-mated mated queen and nestmate relatedness is $75 \%$. There is, however, considerable variation in social structure among extant populations and species. Polygyny (multiple queens per colony) and polyandry (multiple mating of queens) occur frequently (Bourke and Franks, 1995; Crozier and Pamilo, 1996) decreasing the genetic relatedness among nestmates.

An exceptionally derived form of social organisation is found in the so-called unicolonial ants. In these societies nest boundaries disappear and supercolonies are formed in which workers and queens freely move around (Passera, 1994). Well studied examples of species forming unicolonial populations are the Argentine ant Linepithema humile, the red imported fire ant Solenopsis invicta, and the red ant Myrmica rubra. In all these cases colonies are

Correspondence: JJ Boomsma, Zoological Institute, University of Copenhagen, Universitetsparken 15, DK-2100 Copenhagen, Denmark. E-mail: JJBoomsma@zi.ku.dk

Received 10 October 2001; accepted 27 March 2002 highly polygynous, aggression among nests is absent, and populations consequently become genetically homogeneous with relatedness among nestmates close to zero (eg, Ross et al, 1996; Seppä and Walin, 1996; Holway et al, 1998; Krieger and Keller, 2000).

A unicolonial type of social organisation is expected to be evolutionary unstable because workers help rearing unrelated brood (Sturtevant, 1938; Crozier, 1977; Bourke and Franks, 1995; Queller and Strassmann, 1998) but paradoxically, unicolonial species are among the ecologically most successful ants in the world (Hölldobler and Wilson, 1990; Passera, 1994). The evolutionary origin and maintenance of unicoloniality is thus elusive and a matter of some controversy (eg, Tsutsui et al, 2000; Giraud et al, 2002) as it was recently proposed that several pathways under different genetic and ecological conditions may lead to this social structure (Chapman and Bourke, 2001).

Ants of the genus Myrmica are highly suitable to study the evolution of unicoloniality, because they show an extreme flexibility in kin structure across populations. In both M. sulcinodis (Pedersen and Boomsma, 1997) and $M$. rubra (Seppä and Walin, 1996) kin structures varying from maximum nestmate relatedness (0.75) and single colony-queens to zero relatedness and highly polygynous nests have been observed. Allozyme studies from five different locations showed that worker nestmate relatedness in $M$. sulcinodis ranges from less than 0.06 in 
a population in Denmark to more than 0.50 in the Pyrenees, Russia and Finland (Seppä et al, 1995; Pedersen and Boomsma, 1997). Also, population structure and inbreeding are very variable in this species. In the Pyrenees, nests were very discrete and widely scattered, while on the Danish island of Samsø multiple nests may belong to the same polydomous colony and nest densities are very high, saturating the entire suitable habitat (Pedersen and Boomsma, 1999a,b). Inbreeding was observed in the Pyrenees and in Russia (involving the production of a high frequency of diploid males; Pedersen et al, 1999), while Danish and British populations did not show any detectable inbreeding (Pedersen and Boomsma, 1997). An explanation for this intraspecific variation could be that these Myrmica populations follow a distinct succession of social stages, and that they were in different successional stages at the moment of sampling. This scenario would include an invasive colonisation stage, followed by expansion, increasing population densities and declining nestmate relatedness. The Pyrenean and Russian populations would thus represent an early stage, where genetic bottlenecks have caused a low number of alleles at the sex determination locus, causing the high number of diploid males. When populations survive this stage the genetic variation will gradually increase due to immigration, primarily of long distance-dispersing males. Consequently inbreeding decreases and expansion through nest-budding starts. Low relatedness populations such as the one on the Danish island of Samsø would then represent a later stage in the succession process, which is achieved only in long term stable habitats that can maintain high population densities. These latter populations tend to completely saturate the habitat (Pedersen and Boomsma, 1999a), but it is as yet unclear whether habitat saturation is a cause or an effect of this final development towards a supercolony structure (Rosengren and Pamilo, 1983; see also Discussion).

The purpose of the present paper is to analyse the population structure of two other isolated populations of M. sulcinodis in Denmark, to estimate the genetic differentiation between these populations and the population from the island of Samsø, and to assess whether these populations represent multiple samples of related end points of social development that disperse from island to island, or whether they are independent multiple end points of social succession towards unicoloniality, starting from a single queen colonisation in every population.

\section{Materials and methods}

\section{Sample collection}

The red ant M. sulcinodis is widely distributed from the Apennines to Arctic Scandinavia and from Portugal to East Siberia (Collingwood, 1979). Sampling was carried out in July and August 2000 on Læsø (57 $17^{\prime}$ N, 10 $54^{\prime}$ E), a Danish island in the Kattegat of about $20 \times 12 \mathrm{~km}$. During a period of 4 weeks all potentially suitable habitat of M. sulcinodis (heathland mainly covered with Empetrum nigrum, Calluna vulgaris and Dechampsia flexuosa) was searched. Two discrete populations were found on opposite ends of the island and will be referred to as Læsø1 and Læsø2, respectively. No other M. sulcinodis population was found, but very small populations may have been overlooked (although not within $200 \mathrm{~m}$ from each of the populations, see below).

The two populations were situated ca. $16 \mathrm{~km}$ apart, about the maximum distance possible on the island. As previously found on the island of Samsø (Pedersen and Boomsma, 1999b), both populations turned out to be very dense, with $M$. sulcinodis nests being dominant within the occupied area and other ant species being common only at the edges of the patch (see also Results). All nests of the two populations were mapped by searching every possible nest site in one-by-one metre quadrates. The area around the two populations was also searched thoroughly, both for isolated M. sulcinodis nests and for nests of other ants, in a radius of up to $200 \mathrm{~m}$ or until a road, a dune ridge or dense bushes bordered the suitable habitat. Other ant species were included on the map if found within $10 \mathrm{~m}$ from a $M$. sulcinodis nest. Directly after mapping, nests (usually clearly visible as elevated small earth mounds in between the vegetation) were opened and 2040 workers per nest and all visible winged sexuals were collected. Most males and new queens gather in the upper part of the nest ( $\mathrm{T}$ van der Hammen and JS Pedersen, personal observation), so although some sexuals may have escaped collection the sex ratio and number of individuals obtained are likely to be comparable to studies where complete nests were excavated (eg, Pedersen and Boomsma, 1998; Walin et al, 2001). All ants were brought to the laboratory alive and stored at $-80^{\circ} \mathrm{C}$ until genetic analysis.

Nests used for genetic analysis were chosen by drawing gridlines on the maps and selecting the nests closest to crossings of the gridlines. This resulted in a regular sampling scheme including 14 nests for Læsø1 in a $15 \mathrm{~m}$ grid and 17 nests for Læsø2 in a $6 \mathrm{~m}$ grid (Figure 1). The genetic analysis further included up to 50 workers from 23 randomly chosen nests previously sampled in a single large population on the Danish island of Samsø (situated $138 \mathrm{~km}$ south of Læsø, 55 $56^{\prime} \mathrm{N} 10^{\circ} 36^{\prime} \mathrm{E}$; Pedersen and Boomsma, 1999a).

\section{Molecular genetic analysis}

Ten old workers per nest were analysed for both Læsø1 and Læsø2. Old workers can be recognised by their advanced cuticular melanisation and were chosen because at Samsø workers from different age cohorts are genetically differentiated (Pedersen and Boomsma, 1999a), so that mixing of age cohorts could bias relatedness estimates. DNA was extracted from two legs from each of these workers. The samples were incubated in $100 \mu \mathrm{l} 5 \%$ Chelex (in $10 \mathrm{mM}$ TRIS buffer, $\mathrm{pH} 7.5$ ) at $100^{\circ} \mathrm{C}$ for $15 \mathrm{~min}$. Alternatively a long extraction version (5\% Chelex, $1 \mathrm{~h}$ incubation at $55^{\circ} \mathrm{C}$ and $15 \mathrm{~min}$. incubation at $100^{\circ} \mathrm{C}$ ) or a DNeasy-kit were used to extract DNA. The suspension was stored at $-20^{\circ} \mathrm{C}$ and used directly for PCR. Microsatellite primers developed for $M$. tahoensis (Evans, 1993) were tested and revealed genetic variation at the loci Myrt2 and Myrt4 in M. sulcinodis. PCR conditions were as follows: Myrt2 $\left(94^{\circ} \mathrm{C}\right.$ for 3 min $\left(93^{\circ} \mathrm{C}\right.$ for $30 \mathrm{sec}, 45^{\circ} \mathrm{C}$ for $40 \mathrm{sec}, 72^{\circ} \mathrm{C}$ for $\left.1 \mathrm{~min}\right) \times 40$ cycles followed by $72^{\circ} \mathrm{C}$ for $\left.5 \mathrm{~min}\right)$, Myrt $4\left(94^{\circ} \mathrm{C}\right.$ for $3 \mathrm{~min}$, $93^{\circ} \mathrm{C}$ for $30 \mathrm{sec}, 56^{\circ} \mathrm{C}$ for $40 \mathrm{sec}, 72^{\circ} \mathrm{C}$ for $\left.2 \mathrm{~min}\right) \times 40$ cycles (reduced to 30 cycles when analysed on the automated sequencer) followed by $72^{\circ} \mathrm{C}$ for $1 \mathrm{~h}$ ). PCR amplification was subsequently tested on $2 \%$ agarose gels. Microsatellites were visualised on spreadex S50 and S100 

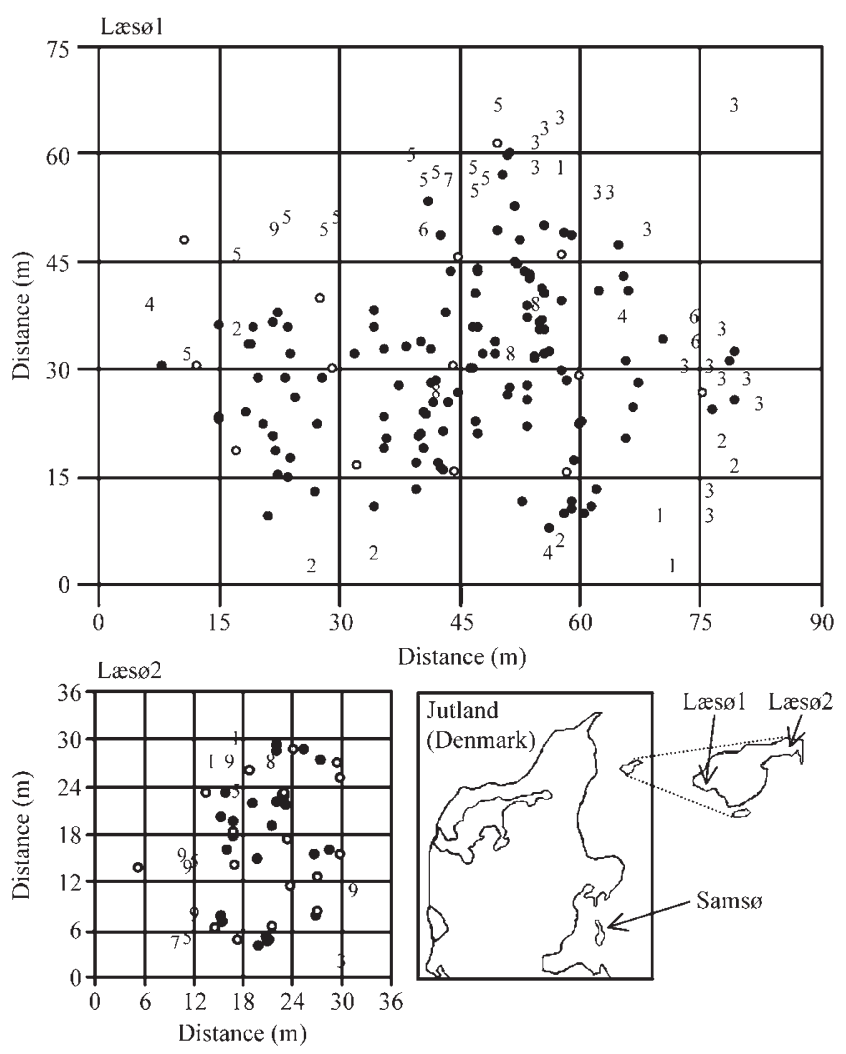

Figure 1 Distribution of Myrmica sulcinodis nests (circles) in the two Læsø populations. M. sulcinodis nests closest to the crossing of gridlines were used for genetical analysis and are indicated with open circles. Nests of other ant species inside the M. sulcinodis population and within an envelope of ca. $10 \mathrm{~m}$ outside the aggregation of $M$. sulcinodis nests are indicated with numbers: (1) M. ruginodis, (2) M. rubra, (3) Formica cinerea, (4) F. rufa, (5) F. fusca, (6) Lasius flavus, (7) L. psammophilus, (8) Leptothorax acervorum, and (9) Tetramorium caespitum.

gels (Kozulic, 1999). Alternatively, when PCR products were ambiguous or spreadex resolution insufficient, analysis was carried out on an ABI 377 automated sequencer.

\section{Statistical analysis}

Exact tests for deviation from Hardy-Weinberg equilibrium within populations, genotypic differentiation of nests within populations, and genotypic differentiation of populations were performed by FSTAT 2.9.1 (Goudet, $1995,2000)$. This program was further used for calculating matrices of pair-wise $F_{\mathrm{ST}}$ estimates for nests within populations. Matrix correlation coefficients and Mantel tests for the association of pair-wise $F_{\mathrm{ST}}$ and geographic distance between nests were calculated by the computer programme ARLEQUIN 2.001 (Schneider et al, 2001). For data including both Læsø populations these statistics were calculated as partial matrix correlations with a third matrix controlling for the fact that nests were only paired with other nests of the same population (Mantel test with nested populations).

Estimates of genetic relatedness $(r)$ among nestmates, inbreeding $\left(F_{\mathrm{IS}}\right)$ and genetic differentiation among populations $\left(F_{\mathrm{ST}}\right)$ were obtained by the computer program RELATEDNESS 4.2c (Goodnight and Queller, 1996), which uses the algorithms developed by Queller and Goodnight
(1989). Average values were found by weighting nests (for estimates of $r$ and $F_{\text {IS }}$ ) or populations (for estimates of $F_{\mathrm{ST}}$ ) equally. Standard errors were obtained by jackknifing over nests ( $r$ and $F_{\text {IS }}$ ) or populations $\left(F_{\mathrm{ST}}\right)$. Parametric $t$-tests were used to test whether estimates of $r$ and $F$ showed significant deviations from zero. The effective queen number $\left(n_{\mathrm{e}}\right)$ was calculated using equations 1 and 5 in Pedersen and Boomsma (1999a). This represents the average number of equally fertile queens per colony that would lead to the estimated relatedness among nestmate workers (cf. Ross, 1993).

\section{Results}

The two populations of M. sulcinodis on Læsø (Læsø1 and Læsø2) consisted of 143 and 44 nests, respectively (Figure 1 ). Within each of the patches M. sulcinodis was very abundant and hardly any other ant nests were found, whereas other ant species were common at the edges and outside the M. sulcinodis nest-aggregations (Figure 1). The nest density in the larger Læsø1 population was lower than in the Læsø2 population (0.064 vs 0.098 nests $/ \mathrm{m}^{2}$ of inhabited area) which is reflected in a significantly longer distance between nearest neighbour nests (distance $\pm \mathrm{SD}=2.1 \pm 1.7$ vs $1.6 \pm 1.8 \mathrm{~m} ;$ Mann-Whitney $U$-test; $P=0.027$ ).

Both microsatellite loci were highly variable with 11 alleles detected at Myrt2 and 21 alleles found at Myrt4 across the two populations (Figure 2). Average expected heterozygosities were 0.64 and 0.85 for Myrt2 and Myrt4, respectively, and $0.70,0.79$ and 0.75 on average for Læsø1, Læsø2 and Samsø, respectively. Estimates of relatedness among nestmate workers were low $(r<0.06)$ but significantly positive for both Læsø populations (Figure 3) with an estimate of $r=0.051 \pm 0.016(P=0.002)$ for the total sample. The positive nestmate relatedness is further confirmed by the highly significant genotypic differentiation of nests (FSTAT, exact tests; $P<0.0001$ for both populations). None of the Læsø populations showed
Myrt2

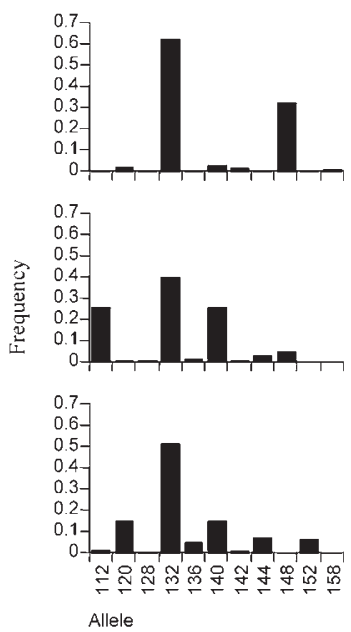

Myrt4

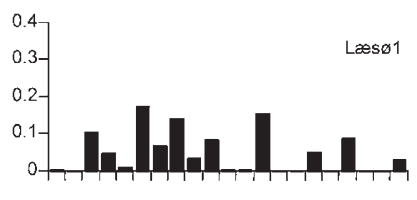

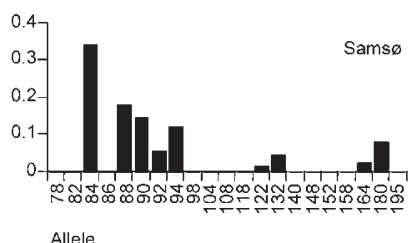

Figure 2 Allele frequencies at the microsatellite loci Myrt2 and Myrt4 (Evans, 1993) in workers of the three Myrmica sulcinodis populations studied: Læsø1 $\left(n_{\text {nests }}=14, n_{\text {alleles-Myrt2 }}=249, n_{\text {alleles- }}\right.$ Myrt4 $=230)$, Læsø2 $\left(n_{\text {nests }}=17, n_{\text {alleles-Myrt2 }}=310, n_{\text {alleles-Myrt4 }}=315\right)$, and Sams $\varnothing\left(n_{\text {nests }}=23, n_{\text {alleles-Myrt2 }}=86, n_{\text {alleles-Myrt4 }}=65\right)$. 

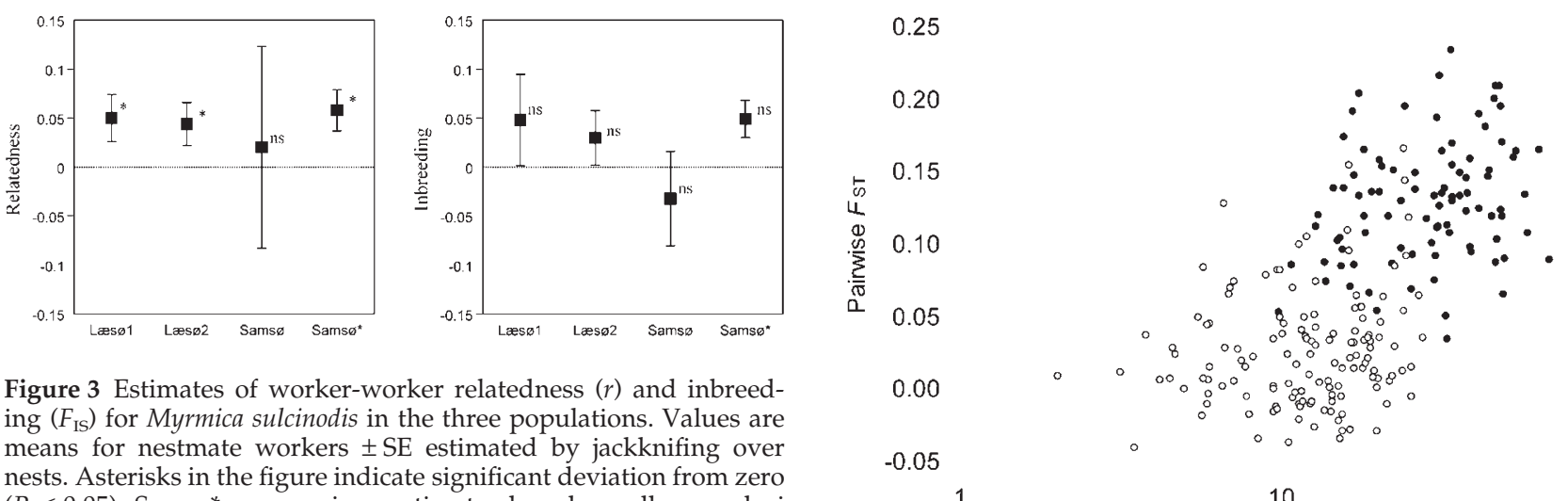

Figure 3 Estimates of worker-worker relatedness $(r)$ and inbreeding $\left(F_{\mathrm{IS}}\right)$ for Myrmica sulcinodis in the three populations. Values are means for nestmate workers $\pm \mathrm{SE}$ estimated by jackknifing over nests. Asterisks in the figure indicate significant deviation from zero $(P<0.05)$. Sams $\varnothing^{*}$ are previous estimates based on allozyme loci from Pedersen and Boomsma (1999a).

any detectable inbreeding (Figure 3; common $F_{\text {IS }}=0.037 \pm 0.024 ; P>0.16$ ) or a significant deviation from Hardy-Weinberg equilibrium at the population level ( $P>0.10$ for both populations). A comparison of these results with estimates of relatedness and inbreeding for Samsø showed that the present markers essentially produce the same results for all three populations. Furthermore, estimates based on microsatellites are equivalent to previous estimates based on allozyme loci (Figure 3 ), the only difference being larger SEs because of lower sample size for the microsatellite analysis of the Samsø population.

The low estimates of worker relatedness result in a high effective queen number per colony, being 16 on average for the Læsø populations under the assumption of random mating and unrelated, single mated and equally reproducing queens. This estimate increases to $n_{\mathrm{e}}=19$ when nestmate queens are assumed to be equally related as nestmate workers, which is common in polygynous ant societies (Crozier and Pamilo, 1996).

The relatedness between workers in pairs of nearest nests on the grid analysed was significantly smaller than the average within-nest relatedness $(\Delta r=0.034 \pm 0.017$; paired $t$-test; $P=0.028$ ) indicating that nests at this scale (6-15 m) are not part of the same polydomous colony. Thus the nests analysed are likely to represent different, independent colonies. However, at the scale of the total population, close nests tend to be more genetically similar than more distant nests as shown by a relatively strong and significantly positive correlation of genetic and spatial distance $(r=0.17$; Figure 4$)$.

Exact tests revealed that the genepools of all three populations studied were significantly differentiated (Bonferroni corrected $P<0.001$ for all three comparisons) with estimates of pairwise $F_{\mathrm{ST}}$ being 0.076 for Læsø1Læsø2 and 0.062 for both Læsø1-Samsø and Læsø2Samsø. The estimated average $F_{\mathrm{ST}}$ among all three populations was $0.067 \pm 0.009$. Hence, the two populations at Læsø, which are about an order of magnitude closer to each other than to the Samsø population, are not genetically more similar to each other than to the population on Samsø

The number of winged sexuals found during sampling at Læsø1 was relatively low $(n=89)$ and all but two were males. This gave a highly male biased numerical sex ratio of 0.978 , corresponding to a relative investment in new queens of only 0.042 (calculation based on dry weights in Pedersen and Boomsma, 1998). The sex ratio of Læsø1

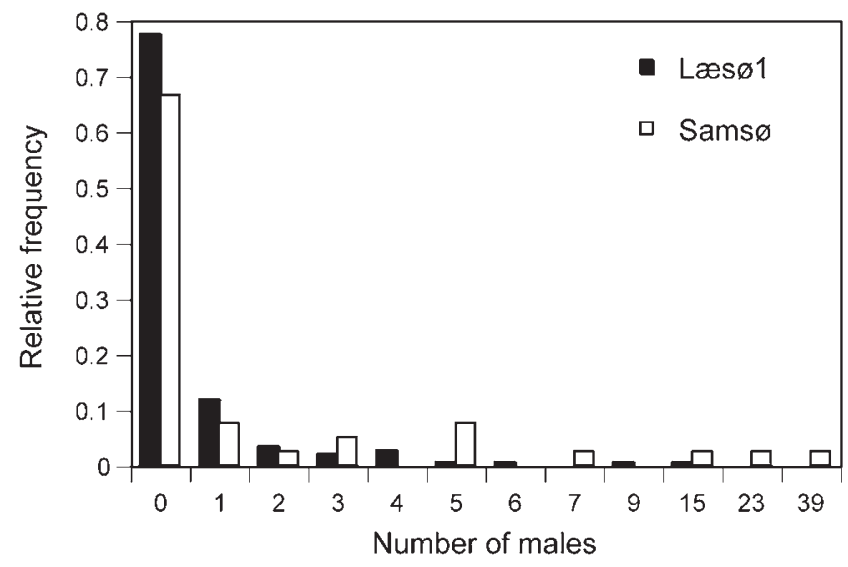

Figure 5 Distribution of males found in nests of the Læsø1 population (closed bars; $n=87$ ) and the Samsø population (open bars; $n=107)$. The two distributions are not significantly different (Mann-Whitney $U$-test; $P=0.18$ ).

was very close to a previous sex-ratio estimate for the Samsø population $(\mathrm{M} / \mathrm{F}=107 / 1$; Pedersen and Boomsma, 1998), and also the distribution of males across nests was remarkably similar for the two populations (Figure 5). Sampling of Læsø2 was too late in the season to find sexuals.

\section{Discussion}

\section{Similar low-relatedness supercolonies}

Both populations of M. sulcinodis on Læsø have essentially the same kin structure as the previously studied population on Samsø. Nest densities were high in all cases, saturating the occupied habitat and effectively excluding all other ant species (Pedersen and Boomsma, 1999a). This is remarkable, because the sizes of the populations were very different. The two Læsø populations differed by a factor three in both area covered and nest number, but both were still small compared to the Samsø 
population, which covered an area of 15 ha and comprised about 11000 nests (Pedersen and Boomsma, 1999a), ie, about two orders of magnitude more than the Læsø populations. The nest density is the same at both islands, being 0.070 nests $/ \mathrm{m}^{2}$ as a weighted mean for the Læsø populations and 0.073 on Samsø. However, the patch structure of the habitat on Samsø results in a more clumped distribution of nests with only $0.35 \pm 0.20 \mathrm{~m}$ as the mean $( \pm S D)$ distance between nearest neighbour nests within patches (Pedersen and Boomsma, 1999b). This illustrates that the Samsø population is very patchy and completely saturated, because virtually every suitable patch is occupied by densely clustered nests of $M$. sulcinodis. This was not the case at Læsø, where empty nest sites still seemed to be available and where the present nests were relatively discrete. The important conclusions of these across-island comparisons are that (1) M. sulcinodis is able to monopolise habitat patches of vastly different sizes, and that (2) such populations have a very similar kin-structure (low, but significantly positive relatedness), breeding system (slightly positive but non-significant inbreeding) and mode of reproduction (extremely male-biased sex ratio).

\section{Genetic differentiation of populations}

Genetic differentiation $\left(F_{\mathrm{ST}}\right)$ among the three $M$. sulcinodis populations studied was highly significant. Moreover, about one-third $(12 / 35)$ of the alleles were only found in a single population and the high variability of the microsatellite markers used most likely implies that genetic differentiation is underestimated by $F$-statistics (Hedrick, 1999). Perhaps surprisingly, a comparison of the pair-wise estimates of $F_{\mathrm{ST}}$ showed that the two Læs $\varnothing$ populations were not genetically more similar to each other than they were to the Samsø population, suggesting that long-distance migration between populations is equally rare at various larger distances and that common alleles are likely to represent the alleles carried by the founding individuals (founder effect).

\section{Where do the new queens come from?}

The extremely male biased sex ratio and the relatively strong correlation of genetic and spatial distance at the scale of total populations (Figure 4) firmly support the argument that the dominant mode of reproduction of $M$. sulcinodis on Læsø is nest budding within the habitat patch. Queens joining a group of workers to initiate a bud-nest avoid the mortality associated with longdistance dispersal and the risk of not finding a suitable nest site after short-distance dispersal. The latter may be particular advantageous in dense, saturated populations where budding is likely to be an optimal strategy for colonies to monopolise resources in the suitable patch (Rosengren and Pamilo, 1983; Pedersen and Boomsma, 1999b). Considerable genetic viscosity, a likely result of nest budding, has earlier been shown to occur in other polygynous ant species of the genera Myrmica (Seppä and Pamilo, 1995), Formica (Chapuisat et al, 1997; Liautard and Keller, 2001), and Rhytidoponera (Tay et al, 1997).

An intriguing remaining question is how lowrelatedness populations of $M$. sulcinodis recruit their replacement queens, as it seems that they hardly produce gynes in most breeding seasons. In an earlier study on Samsø, Pedersen and Boomsma (1998) also found a very low overall sexual productivity of nests (108 sexuals of both sexes in 39 nests over 2 years), whereas the productivity of British populations with moderate nestmate relatedness was an order of magnitude larger (Elmes, 1987; see also below). Although we cannot exclude the possibility that both island studies accidentally sampled bad years for sexual production, in different years and on different locations, this possibility seems less likely than assuming that saturated habitats in fact select for low investment in sexual reproduction, relative to the production of new workers needed for colony budding (cf. Pamilo, 1991). Another case of apparent underproduction of replacement queens was recently reported for a population of M. rubra with comparable social structure (Walin et al, 2001).

As a working hypothesis for explaining the paradox of queen recruitment in $M$. sulcinodis (ie, low rates of production of new queens $v$ s high abundance of breeding queens), we suggest that colonies either must produce more gynes in some breeding seasons that we have so far failed to sample, or that they rely on immigrating queens from isolated nests or long-distance populations with a more distinct kin-structure and a more even sex ratio. Such populations are known to occur in $M$. sulcinodis (see below) and are probably more easily overlooked than saturated populations like the ones investigated on Samsø and in the present study. However, immigration would tend to remove the observed genetic viscosity of the population (Figure 4) and is thus not likely to be a major source of new queens. A third and not mutually exclusive explanation is that $M$. sulcinodis queens are very long-lived, so that these supercolonies can maintain high effective queen-numbers and thus long-term stability with low recruitment of new queens. This contrasts with the common view that a short lifespan is typically expected in polygynous ants (Keller and Genoud, 1997) including Myrmica (Elmes and Petal, 1990; Seppä, 1994; Evans, 1996).

\section{The succession of $M$. sulcinodis populations}

In the introduction we have outlined a hypothetical scenario of how low relatedness supercolonies may develop in $M$. sulcinodis and other polygynous ants. We now return to this scenario for a more detailed discussion in light of the results of the present study.

The long distance between the three genetically differentiated M. sulcinodis populations suggests that they were founded by a single inseminated queen. We realise that we cannot prove this 'single-queen-foundation' scenario, but the alternative explanation based on short distance multiple colonisation followed by extinction of neighbouring, equally polygynous, populations is much less likely. The alternative explanation would automatically raise the question how these larger original populations were founded, which would ultimately require a scenario where the entire island or the area comprising both islands has once been covered by a network of interconnected supercolonies. Such a starting point, followed by gradual but large-scale extinction and substantial genetic drift, could, in theory, explain the differentiation between the three extant supercolonies on the two islands, but there are strong arguments that make this alternative a rather academic case. First, the topography of the island of Læsø indicates that the heathland habitats of the two extant supercolonies at opposite ends of the island have always been separated by zones of lower altitude without 
suitable habitat for M. sulcinodis. Second, this scenario would predict that the allele frequencies of the two Læsø populations are more similar to each other than to the Samsø population, and this is clearly not the case as documented by comparable estimates of pairwise $F_{\mathrm{ST}}$.

Assuming single-queen foundation implies that early colony expansion after colonisation would only have been possible if such single founding colonies in Læsø1 and Læsø2 produced winged reproductives of both sexes and if these young budding populations were able to survive a considerable load from diploid male production and perhaps reduced viability due to inbreeding depression. We know that such populations do exist in M. sulcinodis. Small and scattered populations in both the Pyrenees and Russia are characterised by a high proportion of mating among relatives leading to $F_{\text {IS }}$ values of $0.23-0.33$ and with up to $65 \%$ of the males being sterile diploids (Pedersen and Boomsma, 1997; Pedersen et al, 1999). Many young populations may not survive such a bottleneck, but the few that do would probably start an exponential growth phase of expansion, during which inbreeding depression would gradually diminish owing to occasionally (but still rare) immigrating males or gynes. Intermediate population structures would thus arise, characterised by moderately low relatedness and no detectable inbreeding. Examples of M. sulcinodis populations in this stage of development are known from Dorset, UK, were moderate relatedness of worker nestmates and less male biased sex ratios were found in most years (Stoborough: $r_{\text {workers-old }}=0.366 \pm 0.061 ; F_{\mathrm{IS}}=0.042 \pm$ $0.067 ; n=44$ nests. Winfrith: $r_{\text {workers-old }}=0.346 \pm 0.091$; $F_{\text {IS }}=-0.046 \pm 0.085 ; n=27$ nests. Pedersen, 1997). The final stage of development, perhaps only reached in the most long-lived populations in highly stable habitats, would then be represented by the Danish island populations of Læsø and Samsø, where relatedness approaches zero and where habitat saturation is almost complete.

This hypothetical scenario would predict that marker genes of founders remain dominant in the supercolony for quite some time. This implies the expectation that the allele frequency distribution of each highly variable microsatellite locus should be characterised by two or three common alleles (representing the inseminated founding queen and multiplied during the initial population growth phase) and a series of rare alleles (representing later immigrants). The patterns in Figure 2 do indeed seem to give some support for this idea, especially for the Myrt2 locus. A similar scenario may apply to $M$. rubra, where populations are also highly variable in colony kin-structure (Seppä and Walin, 1996) and where low-relatedness supercolonies have repeatedly been found in isolated, long-term stable habitats (Pearson, 1983; Seppä and Pamilo, 1995; Seppä and Walin, 1996). In M. rubra, development has gone even further in that a smaller, microgyne phenotype of queen has evolved, possibly as an adaptation to the typical kin structure in these supercolonies (Pearson and Child, 1980; Elmes and Keller, 1993).

We conclude that $M$. sulcinodis and most likely also $M$. rubra are apparently able to predictably develop lowrelatedness supercolonies in long-term stable isolated habitats. The mechanism behind this extreme flexibility in the expression of social traits may be convergent natural selection in each patch over a series of queen generations. However, given the limited gene flow between populations, the likely high longevity (and thus long generation time) of queens and the identical end product of these patch-wise developments in spite of large differences in allele frequencies at neutral marker loci, it seems more likely that phenotypic plasticity with contextdependent expression of social traits is responsible for the repeated emergence of low-relatedness supercolonies in Myrmica ants.

A recent paper by Chapman and Bourke (2001) suggested that several pathways may lead to unicolonial structures in social insects depending on the ecological and genetical conditions. The succession of population types known for Myrmica ants is at least partly consistent with the 'ecological pathway' hypothesis, because unicoloniality is ultimately mediated by habitat saturation (Chapman and Bourke, 2001). This scenario allows that genetic processes interact with habitat saturation processes. Our study adds considerable detail to this scenario for a single case in point and indicates that these genetic effects are perhaps most prominent during the intermediate stages of social development towards supercolonies in Myrmica ants.

\section{Acknowledgements}

We thank Thomas Damm Als, Pia Gertsch, Sylvia Mathiassen, Seirian Sumner, and David Nash for technical assistance and helpful discussions. Andrew Bourke, Michel Chapuisat, Perttu Seppä, and an anonymous referee provided constructive comments on previous versions of the manuscript. This study was supported by grants from the Danish National Science Research Council, the Swiss National Science Foundation, the EU SOCRATES exchange programme and the EU Research Training Network "INSECTS" established under the Improving Human Potential programme (HPRN-CT2000-00052).

\section{References}

Bourke AFG, Franks NR (1995). Social Evolution in Ants. Princeton University Press: Princeton, New Jersey.

Chapman RE, Bourke AFG (2001). The influence of sociality on the conservation biology of social insects. Ecol Letters 4: 650662.

Chapuisat M, Goudet J, Keller L (1997). Microsatellites reveal high population viscosity and limited dispersal in the ant Formica paralugubris. Evolution 51: 475-482.

Collingwood CA (1979). The Formicidae (Hymenoptera) of Fennoscandia and Denmark. Scandinavian Science Press: Klampenborg.

Crozier RH (1977). Evolutionary genetics of the Hymenoptera. Annu Rev Entomol 22: 263-288.

Crozier RH, Pamilo P (1996). Evolution of Social Insect Colonies: Sex Allocation and Kin Selection. Oxford University Press: Oxford.

Elmes GW (1987). Temporal variation in colony populations of the ant Myrmica sulcinodis. II. Sexual production and sex ratios. J Anim Ecol 56: 573-583.

Elmes GW, Keller L (1993). Distribution and ecology of queen number in ants of the genus Myrmica. In: Keller L (ed) Queen Number and Sociality in Insects, Oxford University Press: Oxford. pp 294-307.

Elmes GW, Petal J (1990). Queen number as an adaptable trait: evidence from wild populations of two red ant species (genus Myrmica). J Anim Ecol 59: 675-690.

Evans JD (1993). Parentage analyses in ant colonies using simple sequence repeat loci. Mol Ecol 2: 393-397. 
Evans JD (1996). Queen longevity, queen adoption, and posthumous indirect fitness in the facultatively polygynous ant Myrmica tahoensis. Behav Ecol Sociobiol 39: 275-284.

Giraud T, Pedersen JS, Keller L (2002). Evolution of supercolonies: the Argentine ants of southern Europe. Proc Natl Acad Sci USA 99: 6075-6079.

Goodnight KF, Queller DC (1996). Relatedness 4.2c. Goodnight Software: Houston. Available at http://gsoft.smu.edu/ GSoft.html.

Goudet J (1995). FSTAT (version 1.2): a computer program to calculate F-statistics. I Hered 86: 485-486.

Goudet J (2000). FSTAT, a program to estimate and test gene diversities and fixation indices 2.9.1. Institute of Ecology, University of Lausanne: Lausanne. Available at http://www.unil.ch/ izea/softwares/fstat.html.

Hamilton WD (1964). The genetical evolution of social behaviour I-II. J Theor Biol 7: 1-52.

Hedrick PW (1999). Perspective: highly variable loci and their interpretation in evolution and conservation. Evolution 53: 313-318.

Hölldobler B, Wilson EO (1990). The Ants. Springer-Verlag: New York.

Keller L, Genoud M (1997). Extraordinary lifespans in ants and termites: a test of evolutionary theories of ageing. Nature 389 : 958-960.

Kozulic B (1999). Electrophoresis on novel gel matrices. Food Technol Biotechnol 37: 45-49.

Krieger MJB, Keller L (2000). Mating frequency and genetic structure of the Argentine ant Linepithema humile. Mol Ecol 9: 119-126.

Liautard C, Keller L (2001). Restricted effective queen dispersal at a microgeographic scale in polygynous populations of the ant Formica exsecta. Evolution 55: 2484-2492.

Pamilo P (1991). Evolution of colony characteristics in social insects. II. Number of reproductive individuals. Am Natur 138 412-433.

Passera L (1994). Characteristics of tramp species. In: Williams DF (ed) Exotic Ants: Biology, Impact, and Control of Introduced Species, Westview Press: Boulder, Colorado. pp 23-43.

Pearson B (1983). Intra-colonial relatedness amongst workers in a population of nests of the polygynous ant, Myrmica rubra Latreille. Behav Ecol Sociobiol 12: 1-4.

Pearson B, Child AR (1980). The distribution of an esterase polymorphism in macrogynes and microgynes of Myrmica rubra Latreille. Evolution 34: 105-109.

Pedersen JS (1997). Variation in Social and Genetic structure in the Red Ant, Myrmica sulcinodis. PhD Thesis, University of Aarhus.

Pedersen JS, Boomsma JJ (1997). Genetic diversity and variation of social structure in ant populations. In: Kipyatkov VE (ed) Proceedings of the International Colloquia on Social Insects, vol 34, Socium: St. Petersburg. pp 157-172.
Pedersen JS, Boomsma JJ (1998). Direct genetic evidence for local mate competition in ants. Naturwiss 85: 593-595.

Pedersen JS, Boomsma JJ (1999a). Effect of habitat saturation on the number and turnover of queens in the polygynous ant, Myrmica sulcinodis. I Evol Biol 12: 903-917.

Pedersen JS, Boomsma JJ (1999b). Genetic analysis of colony structure in polydomous and polygynous ant populations. Biol J Linn Soc 66: 115-144.

Pedersen JS, Kipyatkov VE, Als TD, Boomsma JJ (1999). Inbreeding depression in social insects: the production of sterile males in marginal ant populations. Proceedings of the 7th Congress of ESEB, ESEB: Barcelona.

Queller DC, Goodnight KF (1989). Estimating relatedness using genetic markers. Evolution 43: 258-275.

Queller DC, Strassmann JE (1998). Kin selection and social insects. Bioscience 48: 165-175.

Rosengren R, Pamilo P (1983). The evolution of polygyny and polydomy in mound-building Formica ants. Acta Entomol Fennica 42: 65-77.

Ross KG (1993). The breeding system of the fire ant Solenopsis invicta, and its effects on colony genetic structure. Am Natur 141: 554-576.

Ross KG, Vargo EL, Keller L (1996). Social evolution in a new environment: the case of the introduced fire ants. Proc Natl Acad Sci USA 93: 3021-3025.

Schneider S, Roessli D, Excoffier L (2001). Arlequin: a software for population genetics data analysis 2.001. Genetics and Biometry Laboratory, University of Geneva: Geneva. Available at http:/ / anthro.unige.ch/arlequin.

Seppä P (1994). Sociogenetic organization of the ants Myrmica ruginodis and Myrmica lobicornis: number, relatedness and longevity of reproducing individuals. I Evol Biol 7: 71-95.

Seppä P, Pamilo P (1995). Gene flow and population viscosity in Myrmica ants. Heredity 74: 200-209.

Seppä P, Sundström L, Punttila P (1995). Facultative polygyny and habitat succession in boreal ants. Biol J Linn Soc 56: 533-551.

Seppä P, Walin L (1996). Sociogenic organization of the red ant Myrmica rubra. Behav Ecol Sociobiol 38: 207-217.

Sturtevant AH (1938). Essays on evolution. II. On the effects of selection on social insects. Quart Rev Biol 13: 74-76.

Tay WT, Cook JM, Rowe DJ, Crozier RH (1997). Migration between nests in the Australian arid-zone ant Rhytidoponera sp. 12 revealed by DGGE analyses of mitochondrial DNA. Molec Ecol 6: 403-411.

Tsutsui ND, Suarez AV, Holway DA, Case TJ (2000). Reduced genetic variation and the success of an invasive species. Proc Natl Acad Sci USA 97: 5948-5953.

Walin L, Seppä P, Sundström L (2001). Reproductive allocation within a polygyne, polydomous colony of the ant Myrmica rubra. Ecol Entomol 26: 537-546. 